BRD 50297

\title{
Angiogenesis in Developing Rat Brain: an In Vivo and In Vitro Study
}

\author{
PATRICIA L. ROBERTSON, MONICA DU BOIS, PHILLIP D. BOWMAN and GARY W. GOLDSTEIN \\ Departments of Pediatrics and Neurology, University of Michigan, Ann Arbor, MI 48109 (U.S.A.)
}

(Accepted May 21st, 1985)

Key words: angiogenesis - cultured endothelial cells - $\left[{ }^{3} \mathrm{H}\right]$ thymidine autoradiography endothelial cell growth factor - rat brain development

\begin{abstract}
Brain capillary proliferation in postnatal rats was measured in vivo by $\left[{ }^{3} \mathrm{H}\right]$ thymidine autoradiography. Maximal capillary proliferation occurred between 5 and 9 postnatal days, and was 40 times greater than in the adult. To test the hypothesis that soluble angiogenesis factors play a role in this developmental vascularization of brain, we prepared extracts from the brains of 6-day-old rats at the peak of proliferative activity, and from adults when it was lowest. We assayed them using an in vitro growth system measuring [ $3 \mathrm{H}$ ]thymidine incorporation into cultured brain capillary endothelial cells. Extracts prepared from either 6-day or adult rats and containing $150 \mu \mathrm{g} / \mathrm{ml}$ protein caused more than a 4 -fold stimulation of the endothelial cells, increasing to 8 -fold at a concentration of $1500 \mu \mathrm{g} / \mathrm{ml}$. The presence of growth-promoting activity in brain extracts from both adult and immature rats suggests that soluble angiogenesis factors may be present in the brain throughout life, but are unavailable for stimulation of in vivo capillary growth unless released or activated by an appropriate stimulus.
\end{abstract}

\section{INTRODUCTION}

The density of capillaries in mammalian brain increases several-fold during development ${ }^{7,8,10}$. The biochemical mechanisms that control this microvascular growth and determine the final capillary density, however, have not been studied. During the past decade, soluble substances capable of stimulating capillary growth have been identified in other tissues with active neovascularization such as diabetic retina and tumors of various origins ${ }^{13,14}$. Because brain capillary endothelium is separated from neurons and glia by an extracellular basement membrane, it seems likely that a signal for brain angiogenesis must also be soluble in order to stimulate the endothelial cells across this membrane. To define the role of soluble factors in developmental angiogenesis of brain, we first determined the postnatal time course of capillary proliferation in rat brain, and then tested homogenates of brain during the peak of proliferation for their ability to stimulate thymidine incorporation into cultured brain capillary endothelial cells. Abstracts of this work have been published 22.23 .

\section{MATERIALS AND METHODS}

\section{In vivo capillary proliferation in postnatal rats}

Sprague-Dawley albino rats were used throughout. Pregnant dams were housed in the laboratory, and pups were used after birth at various ages to establish the time-course of capillary proliferation in the developing brain. The rats were injected intraperitoneally at noon of the appropriate day with $3 \mu \mathrm{Ci} / \mathrm{g}$ of $\left[{ }^{3} \mathrm{H}\right]$ thymidine (New England Nuclear, 79.8 $\mathrm{Ci} / \mathrm{mmol}$ ). After $4 \mathrm{~h}$ the rats were anesthetized with pentobarbital $(50 \mathrm{mg} / \mathrm{kg})$ and perfused via the left ventricle with cold $4 \%$ formaldehyde in phosphatebuffered saline (PBS). The brains were removed, and a $2 \mathrm{~mm}$ coronal block of occipital cortex was fixed for an additional 4 days, embedded in paraffin and sectioned at $6 \mu \mathrm{m}$. Every 50th section was mounted on a microscope slide and stained with Luxol fast blue/PAS. For autoradiography, the slides were dipped in warmed nuclear track emulsion (NTB-3, Kodak, Rochester, NY) and air-dried for 2 $\mathrm{h}$ in the dark. To minimize exposure time, the sections were soaked in cold Aquasol scintillation fluid

Correspondence: P. Robertson. University of Michigan, Pediatric Neurology, R6060 Kresge II, Ann Arbor, MI 48109, U.S.A. 
(New England Nuclear) for $2 \mathrm{~min}$ and air-dried for 31 min25. After exposure of the slides for $1.5-2$ weeks at $4{ }^{\circ} \mathrm{C}$, they were developed. The percentage of labeled capillary cells (labeled cells/total capillary cells) or labeling index was determined for each section, in an area of occipital cortex extending $2 \mathrm{~mm}$ laterally from the midline. Capillary cells include both endothelial cells and pericytes. The index at each time point is the average of 3 animals

\section{In vitro stimulation of capillary endothelium by brain extracts}

Extracts prepared from rat brain were tested for their capacity to stimulate $\left[{ }^{3} \mathrm{H}\right]$ thymidine incorporation into cultured brain capillary endothelial cells. Brain extracts from 6-day and adult rats were prepared by sacrificing the animal by cervical dislocation and homogenizing the brain in Alpha Minimal Essential Medium ( $\alpha$ MEM, $1 \mathrm{~g}$ brain $/ 4 \mathrm{ml}$ ) in a glass homogenizer with a teflon pestle until cell nuclei were freed from cytoplasm. The homogenates were centrifuged at $32,000 \mathrm{~g}$ for $30 \mathrm{~min}$, and the supernatants recentrifuged at $100,000 \mathrm{~g}$ for $1 \mathrm{~h}$. The resulting supernatants were used to test for stimulation of endothelial cells. All operations were carried out at $4{ }^{\circ} \mathrm{C}$. Total protein concentration of each extract was determined by the Bio-Rad Coomassie blue method. Extracts were stored at $-70^{\circ} \mathrm{C}$ until use.

Capillary endothelial cells were derived from bovine brain as previously described and used at first passage ${ }^{3}$. Cells were plated in 24-well multiplates that had been previously coated with fibronectin, at a density of 20,000 cells $/ \mathrm{ml}$, with medium containing $10 \%$ plasma-derived serum (PDS). Cells were used when they became confluent about one week after plating. The medium containing $10 \%$ PDS was then removed and replaced with extract at various concentrations of protein with $\alpha$-MEM and $0.5 \%$ fetal calf serum. After $20 \mathrm{~h}$ the cells were incubated with $0.5 \mathrm{ml}$ of $\mathrm{MEM}$ containing $0.4 \mu \mathrm{Ci} / \mathrm{ml}$ of $\left[{ }^{3} \mathrm{H}\right]$ thymidine for $2 \mathrm{~h}$. The medium was removed and the cells fixed for $15 \mathrm{~min}$ with $2.5 \%$ glutaraldehyde, washed 3 times with $70 \%$ ethanol and for several hours with running tap water. After air-drying, the cells were incubated for $2 \mathrm{~h}$ with $0.4 \mathrm{ml}$ of $1 \mathrm{~N} \mathrm{HCl}$ at $65^{\circ} \mathrm{C}$ to hydrolyze the DNA. The $\mathrm{HCl}$ extracts were placed in vials with $5 \mathrm{ml}$ ACS scintillation cocktail (Amersham) and counted in a scintillation counter.
RESIITS

Endothelial cells and pericytes in the capllates the rat occipital cortex readily incorporate $/ \mathrm{H} /$ th midine as they prepare to undergo cell division in th first weeks of life (Fig. 1). The percentage of label cells (thymidine labeling index) was established ats function of postnatal age. The peak of capillary pr liferation occurred between 5 and 9 dars of as (Fig. 2). During this time approximately $12 \%$ of $t$ capillary cell (endothelial cell plus pericyte) nucl were labeled compared to $0.3 \%$ in the adult $r$ brain. By 20 days the labeling index had dropped 1 $3.1 \%$, and by 25 days was $0.4 \%$. Rat brain extracts:

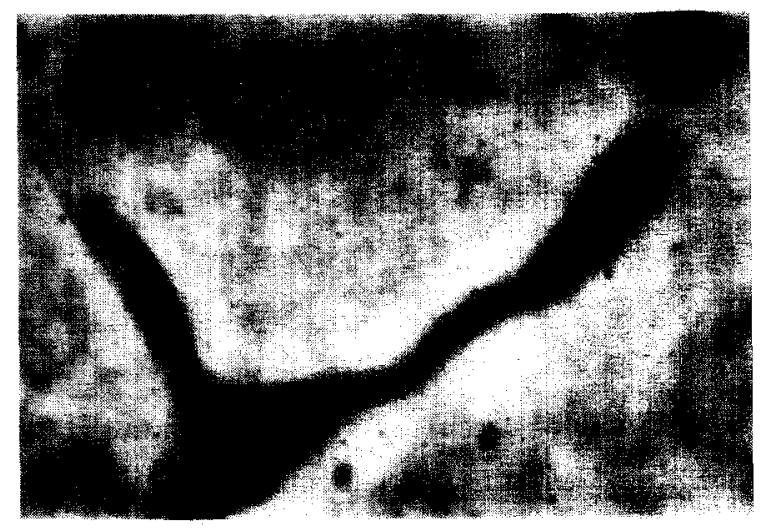

Fig. 1. Autoradiograph of a capillary in rat cerebral cortc demonstrating several capillary cells labeled with $|\mathrm{H}|$ thym dine. $100 \times$.

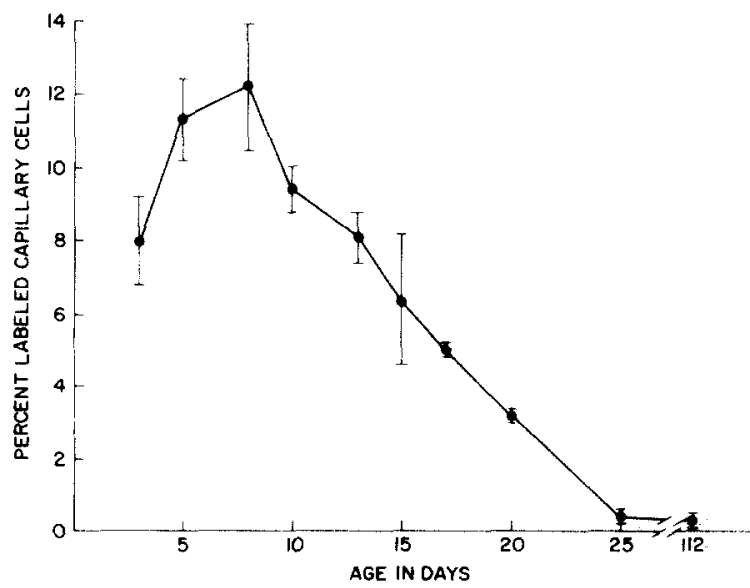

Fig. 2. The percentage of capillary cells (endothelial cells plu pericytes) in rat cerebral cortex labeled with $\left[{ }^{3} \mathrm{H}\right]$ thymidine as function of postnatal age. Each point is the average of 3 dete minations \pm S.E.M. 


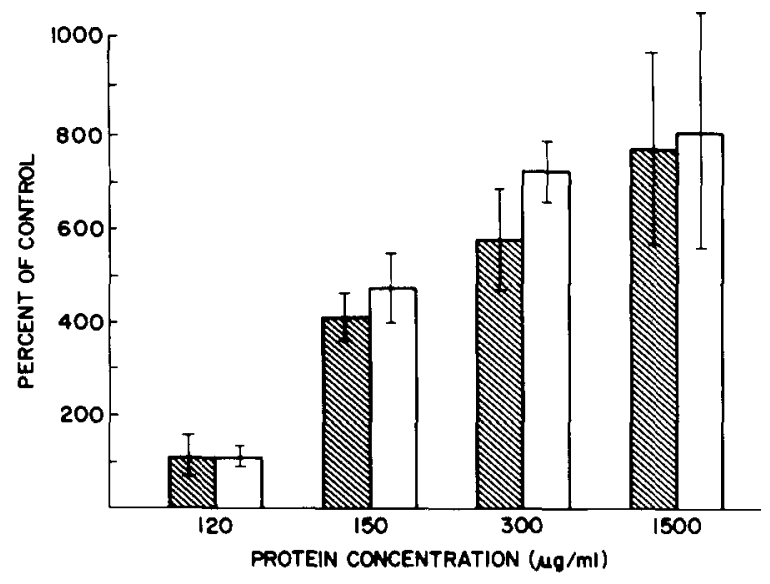

Fig. 3. $\left[{ }^{3} \mathrm{H}\right]$ thymidine incorporation into brain capillary endothelial cells after stimulation by rat brain extracts. Hatched bars indicate 6-day extracts; open bars are adult extracts. Results are the average of 6 determinations \pm S.D. No significant difference exists between adult and 6-day extracts at 150 and $1500 \mu \mathrm{g} / \mathrm{ml}$. At $300 \mu \mathrm{g} / \mathrm{ml}$, the stimulation by adult extract is slightly greater than that of the 6-day extract $(P<0.05)$.

several concentrations of protein stimulated $\left[{ }^{3} \mathrm{H}\right]$ thymidine incorporation into cultured brain capillary endothelial cells. Extracts of both 6-day and adult rat brain caused stimulation that was 4 times that of control at $150 \mu \mathrm{g} / \mathrm{ml}$, and increased to 8 times control at $1500 \mu \mathrm{g} / \mathrm{ml}$ (Fig. 3).

\section{DISCUSSION}

Angiogenesis, the formation of new blood vessels in vivo, appears to involve at least several components. These include endothelial cell migration and degradation of capillary basement membrane, as well as endothelial mitosis and subsequent proliferation. This study focused on this latter aspect of angiogenesis. We found that the rate of capillary proliferation in the neocortex of the developing rat, measured by in vivo $\left[{ }^{3} \mathrm{H}\right]$ thymidine incorporation, was 40 times greater than in the adult (Fig. 2). The peak of proliferation occurs between 5 and 9 postnatal days and is temporally related to several-fold increases in the activity of a number of measures of oxidative metabolism in rat cortex, including oxygen consumption, oxidative enzyme content and mitochondrial density $6,24,26$. This correlation between capillary proliferation and aerobic metabolism suggests that capillary growth might occur in response to changing metabolic demands of the brain during development.
Support for this possibility is found in the neovascularization that occurs in brain in response to pathologic stimuli such as chronic hypoxemia or ischemic injury $4,9,11,12,21$.

The fundamental importance of polypeptide growth factors in maintaining viability and stimulating growth of cells is a generally accepted principal of developmental biology. Soluble factors which promote the growth of blood vessels are present in a number of tissues in which active neovascularization occurs $13,14,18$. The brain in particular contains a number of growth factors including astrocyte growth factor, Schwann cell growth factor, brain-derived growth factor, fibroblast growth factor and endothelial cell growth factor ${ }^{1,5}, 15,19$. The last two of these stimulate some endothelial cells in vitro. Endothelial cell growth factor is a polypeptide that is isolated from bovine brain and hypothalamus. It has a molecular weight in the range of $20 K_{d}$ and an isoelectric point of $\mathrm{pH} 5.5$, and stimulates human umbilical vein and bovine capillary endothelium in vitro ${ }^{19}$. Fibroblast growth factor is another bovine brain derived peptide of similar molecular weight, but with an isoelectric point of $\mathrm{pH} 9.6$, also shown to stimulate large vessel endothelium ${ }^{15}$. The role of these various factors in normal development of brain vasculature, however, is unknown.

After establishing that a period of marked capillary proliferation occurs postnatally in the rat cerebral cortex, we tested the hypothesis that soluble factors are present during this time, which may play a role in the regulation of developmental angiogenesis. Using an in vitro assay we measured $\left[{ }^{3} \mathrm{H}\right]$ thymidine incorporation into brain capillary endothelial cells. We chose these cells for the assay of the extracts because they seem most likely to be the cells stimulated by potential angiogenic factors in vivo. Capillary endothelial cells are different from those of large blood vessels, and brain capillaries in particular have unique functional characteristics such as the presence of tight junctions and a paucity of pinocytotic vesicles that are responsible for formation of the blood-brain barrier in vivo ${ }^{3}$. Large vessel endothelium is rarely, if ever, the target of angiogenic factors in vivo, especially in brain, and may well respond differently to these stimuli in vitro. We found an 8-fold stimulation of brain capillary endothelial cells by extracts prepared from 6-day and adult rat brain (Fig. 3). The 
presence of potent growth-promoting activity for these cells in adult brain when almost no capillary proliferation occurs, as well as in immature brain when proliferation is maximal, suggests that if the factor(s) mediating this activity are responsible for developmental angiogenesis, they are present throughout life but are unavailable for stimulation of in vivo capillary growth unless released or activated by an appropriate stimulus. The correlation between capillary proliferation and aerobic metabolism noted above suggests that such a stimulus may be linked to the changing metabolic demands of the brain during development. Alternatively, the regulation of capillary growth by soluble factors could be modulated by changes in receptors for the factor rather than (or in addition to) changes in the level or availability of the factor itself. A precedent for this kind of developmental adjustment exists in the reorganization of neurochemical circuitry during development, where receptors for acetylcholine and glutamate, for exam-

\section{REFERENCES}

1 Barritault, D., Plouet, J., Courty, J. and Courtols, Y., Purification, characterization, and biological properties of the eye-derived growth factor from retina: analogies with brain derived growth factor, J. Neurosci. Res., 8 (1982) 477-490.

2 Beck, D.W., Hart, M.N. and Cancilla, P.A., The role of the macrophage in microvascular regeneration following brain injury, J. Neuropathol. Exp. Neurol., 42 (1983) 601-614

3 Bowman, P.D., Ennis, S.R., Rarey, K.E., Betz, A.L., and Goldstein, G.W., Brain microvessel endothelial cells in tissue culture: a model for study of blood-brain barrier permeability, Ann. Neurol., 14 (1983) 396-402.

4 Brand, M.M. and Bignami, A., The effects of chronic hypoxia on the neonatal and infantile brain, Brain, 92 (1969) $233-254$.

5 Brockes, J.P., Mitogenic growth factors and nerve dependence on limb regeneration, Science, 225 (1984) 1280-1285.

6 Caley, D.W., An Electron and Light Microscope Study of the Postanatal Development of Rat Cerebral Cortex, Dissertation, University of California, Los Angeles, 1966.

7 Caley, D.W. and Maxwell, D.S., Development of the blood vessels and extracellular spaces during postnatal maturation of rat cerebral cortex, J. Comp. Neurol., 138 (1970) 31-48.

8 Craigie, E.H., Postnatal changes in vascularity in the cerebral cortex of the male albino rat, J. Comp. Neurol., 39 (1925) 301-324.

9 Diemer, K. and Henn, R., Kapillarvermehrung in der Hirnrinde der Ratte unter chronischem Sauerstoffmangel, Naturwissenschaften, 52 (1965) 135-136.

10 Diemer, K., Oxygen Transport in Blood and Tissues, Thieme, Stuttgart, 1968, pp. 118-123. ple. are present in higher concentration an airlic stages in various brain regions. decreasmg with ma turation 16.17 . Either of these mechanisms mas als play a role in the stimulation of new capillary growt found after injury of the adult brain by freese lesior and ischemial?

It seems likely that the stimulatory activity of th rat brain extracts is due, at least in part. to one of th endothelial mitogens already isolated from brair Biochemical characterization and exploration of th specificity of this activity are the next steps in learr ing more about the control of brain capillary growt during development.

\section{ACKNOWLEDGEMENTS}

P.L.R. and M.D. were supported by NINCDS Na tional Research Service Award 5T32NS07222. Th, work was supported by Grant ES 02380 from the Na tional Institute of Health.

11 Devic, M. Girard, P.F. and Masson, R., Malformation vasculaires, dans les cardiopathies congenitales et le: anomalies de la charnière occipito-vertebrale, Acta Neurol Belg., 51 (1951) 457-472.

12 Du Bois, M., Bowman, P.D. and Goldstein, G.W. Cellu lar proliferation following ischemic injury in the gerbi brain, J. Cell Biol., 97 (1983) 246a

13 Folkman, J., Merler, E., Abernathy, C. and Williams, G. Isolation of a tumor factor responsible for angiogenesis J. Exp. Med., 133 (1971) 275-288.

14 Glaser, B.M., D'Amore. P.A., Lutty, G.A., Fenselat A.H., Michels. R.G. and Patz. A., Chemical mediators o intraocular neovascularization. Trans. Ophthalmol SoC U.K., $100(1980) 369-372$

15 Gospodarowicz, D., Cheng, J. and Lirette. M.. Bovine brain and pituitary fibroblast growth factors: comparison of their abilities to support the proliferation of human and bovine vascular endothelial cells, J. Cell Biol., 97 (1983) 1677-1685

16 Greenamyre, J.T., Penney, J.P.. Silverstein. F.S Johnston. M.V. and Young, A.B., Transient postnatal expression of glutamate binding sites in globus pallidum. Soc Neurosci. Abstr., 10(1984) 67.5 .

17 Johnston, M.V., Silverstein, F.S., Reinbel, F.O.. Penney, J.B. and Young. A.B.. $\left[{ }^{3} \mathrm{H}\right] \mathrm{QNB}$ binding in homogenates and quantitative autoradiography in sections, Dev. Brain Res., in press.

18 Kumar, S., Shahabuddin, S., Haboubi, N.. West, D.. Arnold, F., Reid. H. and Carr. T., Angiogenesis factor from human myocardial infarcts, Lancet. Aug. 13 (1983) $364-368$.

19 Maciag. T.. Cerundolo, J., Isley, S. Kelley, P. R. and Forand, R. An endothelial cell growth factor from bovine $h$ : pothalamus: identification and partial characterization. 
Proc. Natl. Acad. Sci. U.S.A., 76 (1979) 5674-5678.

20 Maciag T., Mehlman, T. and Friesel, R., Heparin binds endothelial cell growth factor, the principal endothelial cell mitogen in bovine brain, Science, 225 (1984) 932-935.

21 Opitz, E. and Palme, F., Darstellung der Höhenanpassung im Gebirge durch Sauerstoffmangel, Pflügers Arch., 248 (1944) 298-329.

22 Robertson, P.L., du Bois, M. and Goldstein, G.W., Brain capillary proliferation in the developing rat, Ann. Neurol., 14 (1983) 382a.

23 Robertson, P.L., du Bois, M., Bowman, P.D. and Goldstein, G.W., Angiogenic activity in immature rat brain, Neurology, 34 (Suppl. 1) (1984) 292 a.
24 Sellinger, O.Z., Johnson D.E., Santiago, J.C. and Idoyaga-Vargas, V., A study of the biochemical differentiation of neurons and glia in the rat cerebral cortex. In D.H. Ford (Ed.), Neurobiological Aspects of Maturation and Aging, Progress in Brain Res., Vol. 40, Elsevier, Amsterdam, 1973, pp. 331-347.

25 Stanulis, B.M., Sheldon, B.M., Grove, G.L., and Cristofalo, V.J., Scintillation fluid shortens exposure time in autoradiography, J. Histochem. Cytochem., 27 (1979) 13031307.

26 Tyler, D.B. and Van Harreveld, A., The respiration of the developing brain, Am. J. Physiol., 136 (1942) 600-603. 